\title{
The Solvent Effect on Composition and Dimensionality of Mercury(II) Complexes with Picolinic Acid
}

\author{
Željka Soldin $^{1, *(1)}$, Boris-Marko Kukovec ${ }^{2, *}$, Dubravka Matković-Čalogović ${ }^{1}\left(\mathbb{D}\right.$ and Zora Popović $^{1}(\mathbb{C}$ \\ 1 Division of General and Inorganic Chemistry, Department of Chemistry, Faculty of Science, \\ University of Zagreb, Horvatovac 102a, HR-10000 Zagreb, Croatia; dubravka@chem.pmf.hr (D.M.-Č.); \\ zpopovic@chem.pmf.hr (Z.P.) \\ 2 Department of Physical Chemistry, Faculty of Chemistry and Technology, University of Split, \\ Ruđera Boškovića 35, HR-21000 Split, Croatia \\ * Correspondence: zeljka@chem.pmf.hr (Ž.S.); bmkukovec@ktf-split.hr (B.-M.K.)
}

Citation: Soldin, Ž.; Kukovec, B.-M.; Matković-Čalogović, D.; Popović, Z. The Solvent Effect on Composition and Dimensionality of Mercury(II) Complexes with Picolinic Acid. Molecules 2021, 26, 5002. https:// doi.org/10.3390/molecules26165002

Academic Editors: Jürgen Köhler and Victor V. Maltsev

Received: 30 June 2021

Accepted: 14 August 2021

Published: 18 August 2021

Publisher's Note: MDPI stays neutral with regard to jurisdictional claims in published maps and institutional affiliations.

Copyright: (c) 2021 by the authors. Licensee MDPI, Basel, Switzerland. This article is an open access article distributed under the terms and conditions of the Creative Commons Attribution (CC BY) license (https:// creativecommons.org/licenses/by/ $4.0 /)$.
Abstract: Three new mercury(II) coordination compounds, $\{[\mathrm{HgCl}(\text { pic })]\}_{n}(\mathbf{1}),[\mathrm{HgCl}($ pic $)($ picH) $]$ (2), and $[\mathrm{HgBr}(\mathrm{pic})(\mathrm{picH})](3)(\mathrm{picH}=$ pyridine-2-carboxylic acid, picolinic acid) were prepared by reactions of the corresponding mercury(II) halides and picolinic acid in an aqueous (1) or alcoholmethanol or ethanol (2 and 3 ) solutions. Two different types of coordination compounds were obtained depending on the solvent used. The crystal structures were determined by the singlecrystal X-ray structural analysis. Compound 1 is a one-dimensional (1-D) coordination polymer with mercury(II) ions bridged by chelating and bridging $\mathrm{N}, \mathrm{O}, \mathrm{O}^{\prime}$-picolinate ions. Each mercury(II) ion is four-coordinated with a bidentate picolinate ion, a carboxylate $\mathrm{O}$ atom from the symmetry-related picolinate ion and with a chloride ion; the resulting coordination environment can be described as a highly distorted tetrahedron. Compounds $\mathbf{2}$ and $\mathbf{3}$ are isostructural mononuclear coordination compounds, each mercury(II) ion being coordinated with the respective halide ion, $\mathrm{N}, \mathrm{O}$-bidentate picolinate ion, and $\mathrm{N}, \mathrm{O}$-bidentate picolinic acid in a highly distorted square-pyramidal coordination environment. Compounds 1-3 were characterized by IR spectroscopy, PXRD, and thermal methods (TGA/DSC) in the solid state and by ${ }^{1} \mathrm{H}$ and ${ }^{13} \mathrm{C}$ NMR spectroscopy in the DMSO solution.

Keywords: mercury(II); picolinic acid; coordination polymer; mononuclear complex; solvent type; metal-to-ligand ratio

\section{Introduction}

The transition metal coordination compounds have been of great interest over the past decades because of their interesting and diverse structural features and promising applications in different fields of industry. Such compounds can be used in various areas as materials that exhibit desired catalytic, ion-exchange, gas storage, pharmaceutical, luminescence, optical, electronic, or magnetic properties [1-9]. Electron-withdrawing metal ions, such as mercury(II), can change and tune the fluorescent properties of the organic ligands used in a design of coordination compounds [8-13]. Flexible coordination geometry of the mercury(II) ion, varying from tetrahedral to octahedral, enables the formation of different architectures with different properties [2,11,12,14-19]. By changing additional parameters such as the nature of the ligands, type of the counter ions, selection of solvents, metalto-ligand ratios, temperature, $\mathrm{pH}$ etc., it is possible to impact the crystal structures and tune the desired properties of the coordination compounds [20-24]. Deeper understanding of the above-mentioned parameters is crucial for better prediction of the properties and structures of the solid-state materials. Approaches to crystal growth and design, together with the study and understanding of intermolecular interactions, represent one of the main challenges in the field of crystal engineering [25-29].

Pyridine-2-carboxylic acid (picolinic acid, picH) is a very popular and widely used chelating ligand that is able to coordinate to metal ions in an $\mathrm{N}, \mathrm{O}$-bidentate fashion via 
pyridine $\mathrm{N}$ and carboxylate $\mathrm{O}$ atoms. The coordination potential of picolinate ion ( $\mathrm{pic}^{-}$) can be used for designing different metal-organic architectures [30-38]. Indeed, picolinate complexes of almost every metal from the periodic system have been prepared and structurally characterized by now [39], including mercury(II). Monomeric [17] and polymeric [40-42] mercury(II) complexes with picolinate, but also with picolinate derivatives (e.g., methyl, ethyl, $n$-propyl and $i$-propyl esters [41,43] and ethyl ester of 6-methylpicolinate [41]), are known from the literature. The mercury(II) complex $[\mathrm{HgI}(\mathrm{pic})(\mathrm{picH})]$, containing iodide and both picolinate ion and picolinic acid molecule [17], has been prepared previously. As it became evident that slight changes in the preparation procedures (e.g., metal-to-ligand ratio, solvent choice, $\mathrm{pH}$ of the solution, temperature) of mercury(II) complexes with picolinate and its derivatives lead to complexes of various compositions and dimensionalities, the possibility of obtaining new picolinate mercury(II) complexes under defined experimental conditions needed to be examined further. A goal was to correlate the experimental conditions used during syntheses with the composition and dimensionality of the complexes.

A one-dimensional (1-D) mercury(II) coordination polymer with picolinate and chloride ion, namely poly-chloro(pyridine-2-carboxylato- $\left.N, O, \mathrm{O}^{\prime}\right)$ mercury(II), $\{[\mathrm{HgCl}(\mathrm{pic})]\}_{n}(\mathbf{1})$, and two isostructural mononuclear mercury(II) complexes with halide ions (chloride or bromide) and both picolinate ion and picolinic acid molecule, namely chloro(pyridine-2carboxylato- $N, O)$ (pyridine-2-carboxylic acid- $N, O)$ mercury(II) $[\mathrm{HgCl}($ pic)(picH)] (2) and bromo(pyridine-2-carboxylato- $N, O$ )(pyridine-2-carboxylic acid- $N, O$ )mercury(II), $[\mathrm{HgBr}($ pic) (picH)] (3), have been prepared under defined experimental conditions.

\section{Results and Discussion}

\subsection{Syntheses Aspects}

The reactions of mercury(II) chloride and bromide with picolinic acid were studied in aqueous, methanol and ethanol solutions (using two different metal-to-ligand ratios, 1:1 and 1:2) to see how the solvent change and metal-to-ligand ratio would affect the obtained complexes (Scheme 1).

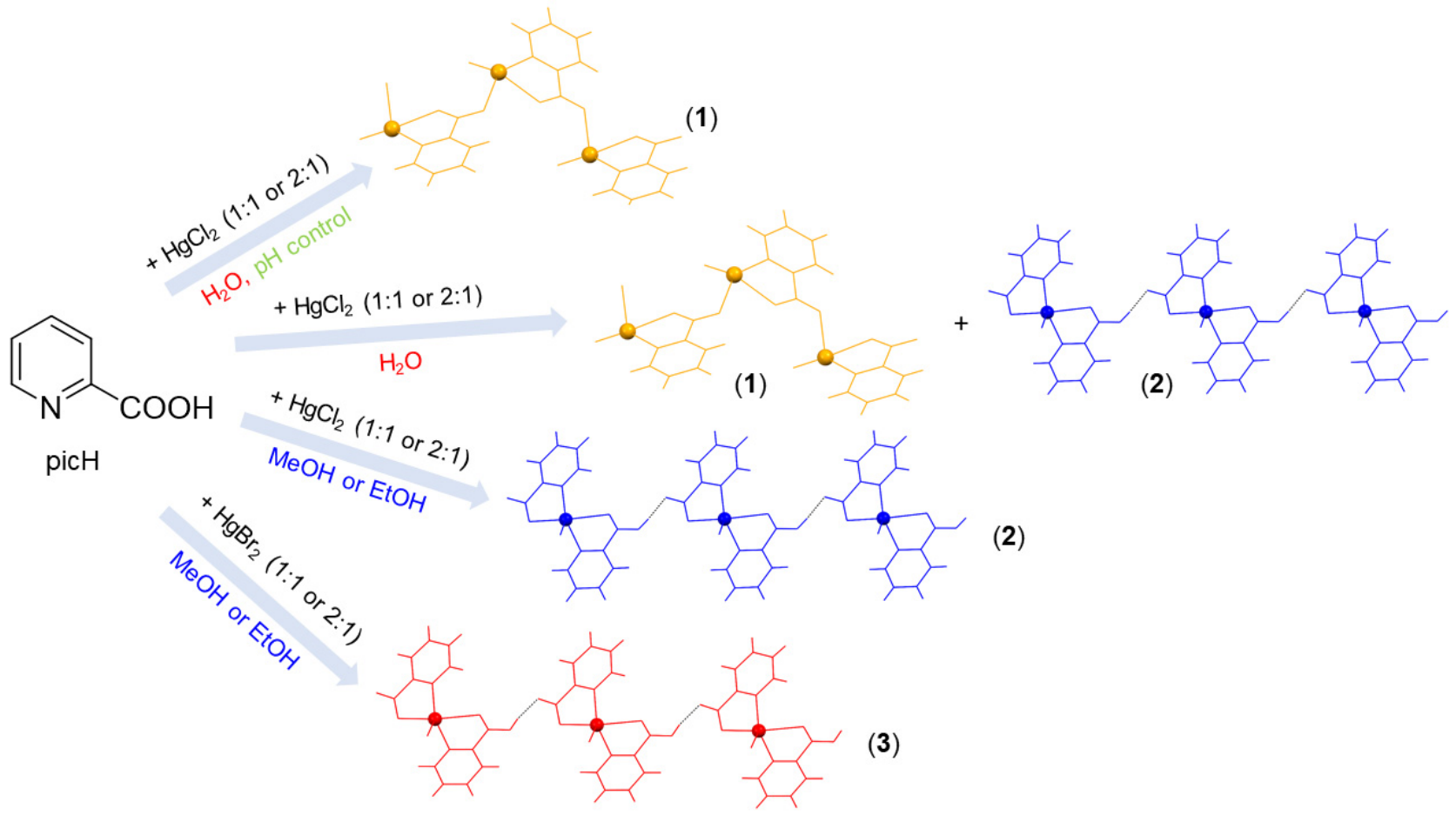

Scheme 1. Preparation of $\{[\mathrm{HgCl}(\text { pic })]\}_{n}(1),[\mathrm{HgCl}(\mathrm{pic})(\mathrm{picH})](2)$ and $[\mathrm{HgBr}(\mathrm{pic})(\mathrm{picH})](3)$ by reactions of pyridine-2carboxylic acid with mercury(II) chloride and mercury(II) bromide, respectively. 
The coordination polymer $\mathbf{1}$ was obtained in an aqueous solution by using a metal-toligand ratio of $1: 1$ or 1:2 and adjusting the $\mathrm{pH}$ of the reaction mixture until precipitation of the compound was completed, while mononuclear complexes 2 and $\mathbf{3}$ were obtained in methanol or ethanol solutions by using a metal-to-ligand ratio of 1:1 or 1:2. Reactions of $\mathrm{HgCl}_{2}$ with picH performed in water solution without increasing the $\mathrm{pH}$ value always led to the mixture of polymeric and mononuclear complexes. Regardless of the metal-toligand ratios (1:1 or 1:2), the mononuclear complex 3 was always obtained. Reactions were performed only in methanol and ethanol due to the very poor solubility of the mercury(II) bromide in water. The presence of water and a slight increase of the $\mathrm{pH}$ value favors the formation of the coordination polymer 1 .

\subsection{Crystal Structures}

The asymmetric unit of $\{[\mathrm{HgCl}(\mathrm{pic})]\}_{n}(\mathbf{1})$ consists of a mercury(II) ion, a chloride ion and a picolinate ion. The mercury(II) ion is four-coordinated with the chloride Cl1 ion, pyridine $\mathrm{N} 1$, and carboxylate $\mathrm{O} 1$ and $\mathrm{O} 2^{\mathrm{i}}$ atoms (symmetry code (i) $x,-y+3 / 2, z+1 / 2$ ), resulting in a coordination environment that can be described as a highly distorted tetrahedron ( $\tau_{4}$ value [44] of 0.67; Figure $1 \mathrm{a}$ and Table S1 in the Supplementary Materials). The adjacent mercury(II) ions in $\mathbf{1}$ are bridged by an $N, O, O^{\prime}$-picolinate ion, thus forming an infinite 1-D polymeric zigzag chain extending in the $\left[\begin{array}{lll}0 & 0 & 1\end{array}\right]$ direction (Figure $2 \mathrm{a}$ ). Each $\mathrm{N}, \mathrm{O}, \mathrm{O}^{\prime}$-picolinate ion acts as a chelating and bridging ligand (via pyridine N1 and carbxylate $\mathrm{O} 1$ atoms, forming a five-membered chelate ring $\mathrm{Hg} 1 / \mathrm{O} 1 / \mathrm{C} 6 / \mathrm{C} 1 / \mathrm{N} 1$, and via carboxylate $\mathrm{O}^{2}{ }^{\mathrm{i}}$ atom) between two neighboring mercury(II) ions (Figure 2a).

The asymmetric units of $[\mathrm{HgCl}(\mathrm{pic})(\mathrm{picH})](2)$ and $[\mathrm{HgBr}($ pic $)(\mathrm{picH})]$ (3) consist of a mercury(II) ion, a halide ion (chloride in 2 and bromide in 3), a picolinate ion, and a picolinic acid molecule (Figure $1 \mathrm{~b}, \mathrm{c}$ ). Compounds 2 and 3 are isostructural, as can be seen from the overlay of the respective molecules of 2 and 3 (Figure 1d). Moreover, both compounds 2 and 3 crystallize in the same space group $\left(P 2_{1} / c\right)$ and with the similar unit cell parameters.

The mercury(II) ion in $\mathbf{2}$ and $\mathbf{3}$ is five-coordinated with pyridine N1 and N2 atoms and carboxylate $\mathrm{O} 1$ and $\mathrm{O} 3$ atoms, which are all situated in a basal plane of a square pyramid, whilst chloride (in 2) or bromide (in 3) ions are placed in the apical position (Figure 1b,c, Table S1 in the Supplementary Materials). The pyridine N1 and N2 atoms are in the trans position (bond angles $\mathrm{N} 1-\mathrm{Hg} 1-\mathrm{N} 2=115.3(2)^{\circ}$ (in 2) and $114.2(4)^{\circ}$ (in 3)); and also, the carboxylate $\mathrm{O} 1$ and $\mathrm{O} 3$ atoms (bond angles $\mathrm{O} 1-\mathrm{Hg} 1-\mathrm{O} 3=135.7(2)^{\circ}$ (in 2) and $136.7(3)^{\circ}$ (in 3)). Both the picolinate ion and the picolinic acid molecule are bound to the mercury(II) ion as chelating ligands, in the $\mathrm{N}, \mathrm{O}$-bidentate mode (via pyridine $\mathrm{N}$ and carboxylate $\mathrm{O}$ atoms) in 2 and 3, forming two five-membered chelate rings (Hg1/O1/C6/C1/N1 and $\mathrm{Hg} 1 / \mathrm{O} 3 / \mathrm{C} 12 / \mathrm{C} 7 / \mathrm{N} 2)$ per molecule. The $\tau$ values [45] (0.08 for $\mathbf{2}$ and 0.02 for $\mathbf{3})$ suggest that the mercury(II) coordination environment in both 2 and 3 can be best described as a square pyramid. The mercury(II) ion is significantly displaced from the center of the basal plane toward the halide ion in both 2 and 3, with a maximum out-of-plane deviation of $1.081(2) \AA$ (in 2) and 1.079(6) ̊ (in 3).

The highly distorted tetrahedral coordination environment in $\mathbf{1}$ can be also seen in a wide range of bond angles around the mercury(II) ion $\left(72.6(2)^{\circ}-147.0(1)^{\circ}\right.$; Table S1 in the Supplementary Materials). The square-pyramidal coordination environments around the mercury(II) ions in 2 and 3 are also highly distorted, as the angles for the trans $\left(115.3(2)^{\circ}-135.7(2)^{\circ}\right.$ in 2 and $114.2(4)^{\circ}-136.7(3)^{\circ}$ in 3$)$ and $c i s\left(68.4(2)^{\circ}-140.6(1)^{\circ}\right.$ in 2 and $68.7(4)^{\circ}-136.7(3)^{\circ}$ in 3) pairs of the ligating atoms indicate (Table S1 in the Supplementary Materials). The reason for such a distortion in $\mathbf{2}$ and $\mathbf{3}$ is probably the $\mathrm{N}, \mathrm{O}$-bidentate binding of both picolinate ion and picolinic acid molecule and the formation of two fivemembered chelate rings per a single molecule, with very small binding angles N1-Hg1-O1 $\left(71.7(2)^{\circ}\right.$ in 2 and $68.7(4)^{\circ}$ in 3), N2-Hg1-O3 $\left(68.4(2)^{\circ}\right.$ in 2 and $71.6(4)^{\circ}$ in 3; Table S1 in the Supplementary Materials). The $\mathrm{Hg}-\mathrm{N}$ and $\mathrm{Hg}-\mathrm{O}$ (pyridine $\mathrm{N}$ and carboxylate $\mathrm{O}$ atoms) 
bond lengths in 1-3 are comparable to those seen in the related mercury(II) complexes containing picolinate ions $[17,40-42]$ and the mentioned picolinate derivatives [41,43].

A fairly similar 1-D mercury(II) coordination polymer with picolinate, $\left\{\left[\mathrm{Hg}(\mathrm{pic})_{2}\right]\right\}_{n}$, is known from the literature $[40,41]$. Although picolinate ions in $\left\{\left[\mathrm{Hg}(\mathrm{pic})_{2}\right]\right\}_{n}$ act in the same way (chelating and bridging ligands) as in $\mathbf{1}$, there are no halide ions in $\left\{\left[\mathrm{Hg}(\mathrm{pic})_{2}\right]\right\}_{n}$, and two picolinate ions bridge two neighboring mercury(II) ions (as opposed to one bridging picolinate in 1), leading to an octahedral coordination of mercury(II) ions in $\left\{\left[\mathrm{Hg}(\mathrm{pic})_{2}\right]\right\}_{n}[40,41]$. The complexes $\mathbf{2}$ and $\mathbf{3}$ are very similar to the known $[\mathrm{HgI}(\mathrm{pic})(\mathrm{picH})]$, but they are not isostructural, as the unit cell parameters and the space group of $[\mathrm{HgI}(\mathrm{pic})(\mathrm{picH})]$ differs [17]. However, while mercury(II) ions in $\mathbf{2}$ and $\mathbf{3}$ exhibit a distorted square-pyramidal coordination, mercury(II) ion in [HgI(pic)(picH)] shows a distorted trigonal-bipyramidal coordination [17].

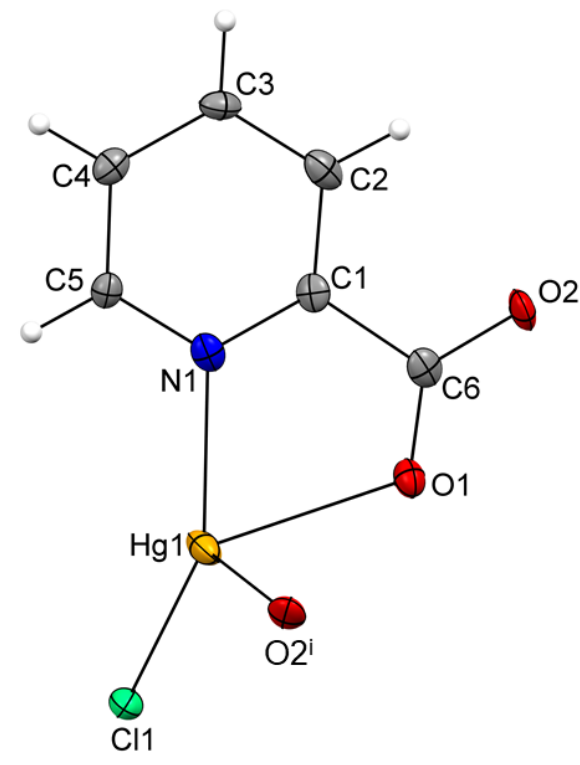

(a)

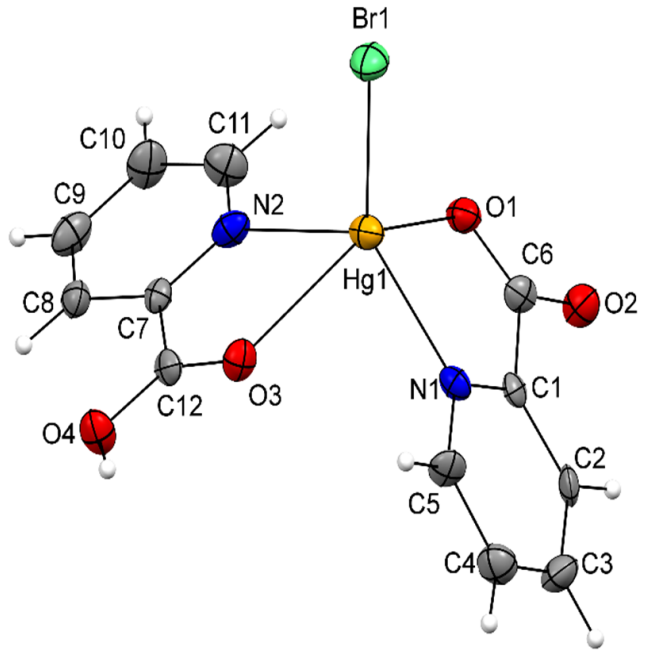

(c)

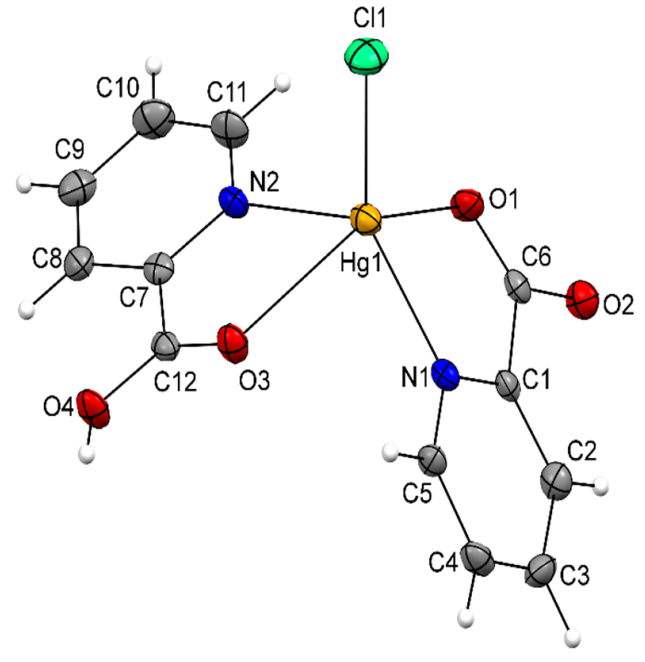

(b)

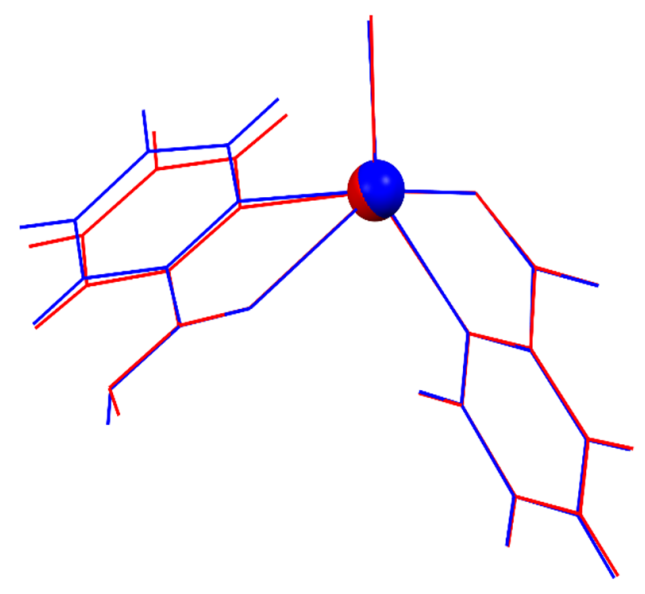

(d)

Figure 1. ORTEP-style plots of $\{[\mathrm{HgCl}(\mathrm{pic})]\}_{n}$ (1) (a), [ $\mathrm{HgCl}($ pic) $(\mathrm{picH})](\mathbf{2})(\mathbf{b})$, and $[\mathrm{HgBr}(\mathrm{pic})(\mathrm{picH})]$ (3) (c), with the atomic numbering schemes. Thermal ellipsoids are drawn at the $40 \%$ probability level at $170(2) \mathrm{K}$, and hydrogen atoms are shown as spheres of arbitrary radii (symmetry code (i): $x$, $-y+3 / 2, z+1 / 2)$. Overlay (RMS value of $0.0556 \AA$ ) (d) of molecules of [ $\mathrm{HgCl}(\mathrm{pic})(\mathrm{picH})]$ (2) (blue) and $[\mathrm{HgBr}(\mathrm{pic})(\mathrm{picH})](3)(\mathrm{red})$. The $\mathrm{Hg}, \mathrm{N}, \mathrm{O}$, and halide atoms were chosen for the overlay. 


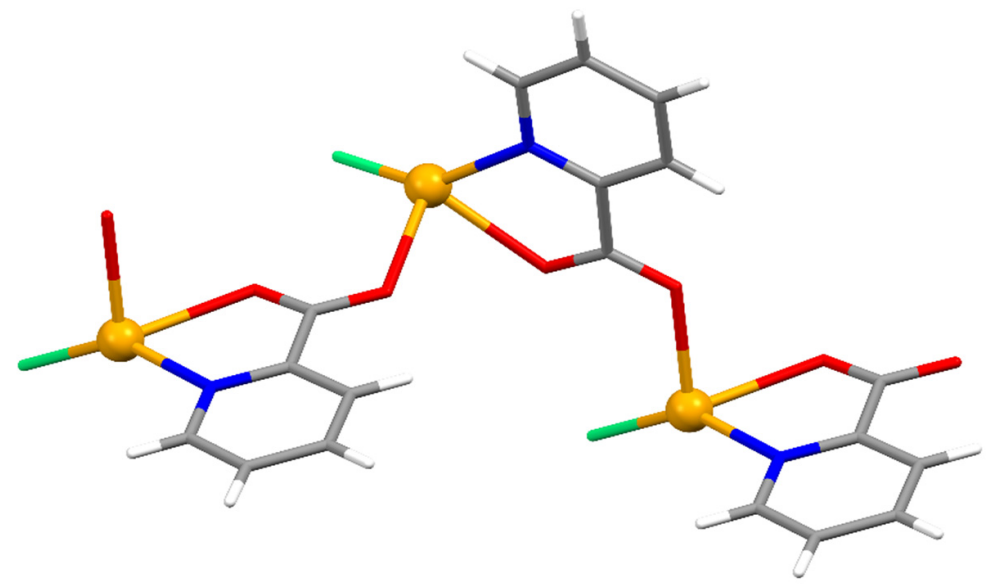

(a)

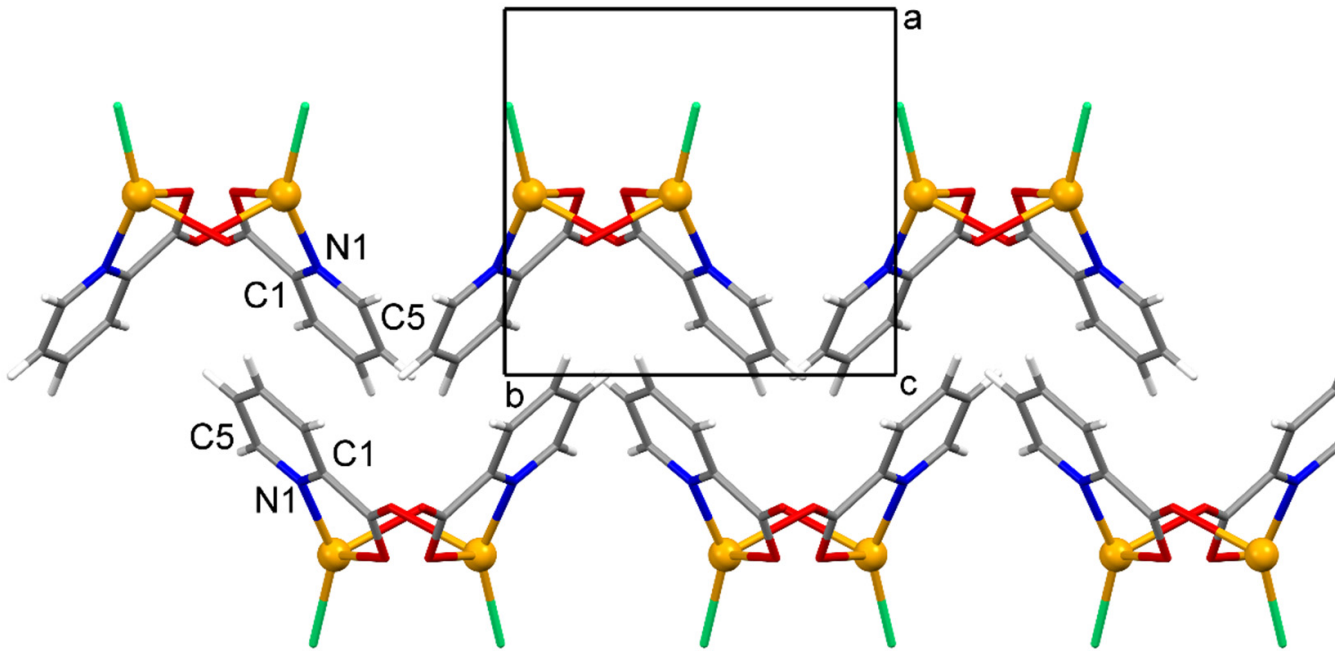

(b)

Figure 2. The infinite one-dimensional polymeric zigzag chain of $\{[\mathrm{HgCl}(\mathrm{pic})]\}_{n}(\mathbf{1})$ extending along the $\left[\begin{array}{lll}0 & 0 & 1\end{array}\right]$ direction (a). A fragment of the structure of $\{[\mathrm{HgCl}(\mathrm{pic})]\}_{n}$ (1) viewed down the [0 0 l 1$]$ direction. The polymeric chains, represented as monomeric molecules in this projection, are connected along the [ $\left[\begin{array}{lll}0 & 1 & 0\end{array}\right]$ direction by $\pi-\pi$ interactions between symmetry-related picolinate pyridine rings $(\mathrm{N} 1 / \mathrm{C} 1-\mathrm{C} 5)$; the selected atoms of the pyridine rings in the interactions are labeled (b).

The crystal structure of $\mathbf{1}$ features no classical hydrogen bonds, while only strong intermolecular $\mathrm{O}-\mathrm{H}$... O hydrogen bonds are present in the crystal structures of $\mathbf{2}$ and $\mathbf{3}$ (Table S2 in the Supplementary Materials). The $\pi-\pi$ interactions [46] are present in all three structures. The described polymeric chains of $\mathbf{1}$, running along the [0 0101$]$ direction, are connected along the [ $\left[\begin{array}{lll}0 & 1 & 0\end{array}\right]$ direction by $\pi-\pi$ interactions between symmetry-related picolinate pyridine rings $[\mathrm{a} \operatorname{Cg} 1 \cdots \operatorname{Cg} 1(-x,-y,-z)$ distance $=3.492(4) \AA$, a dihedral angle between the planes $=0.0(3)^{\circ}$, and a slippage $=1.323 \AA$, where $C g 1$ is the centroid of the picolinate pyridine ring N1/C1-C5] (Figure 2b).

The $[\mathrm{HgCl}(\mathrm{pic})(\mathrm{picH})]$ molecules in 2 and $[\mathrm{HgBr}(\mathrm{pic})(\mathrm{picH})]$ in 3 are connected by the intermolecular $\mathrm{O}-\mathrm{H} \cdots \mathrm{O}$ hydrogen bonds along the $\left[\begin{array}{lll}1 & 0 & 0\end{array}\right]$ direction, giving rise to a hydrogen-bond chain motif $C^{1}{ }_{1}(8)$ (Figure 3a). These hydrogen-bonded chains of $[\mathrm{HgCl}(\mathrm{pic})(\mathrm{picH})]$ in 2 and $[\mathrm{HgBr}(\mathrm{pic})(\mathrm{picH})]$ in 3, respectively, are connected along the $\left[\begin{array}{lll}0 & 1 & 0\end{array}\right]$ direction by $\pi-\pi$ interactions between symmetry-related picolinic acid pyridine rings [a $\operatorname{Cg} 2 \cdots \operatorname{Cg} 2(2-x,-y, 1-z$ in 2 and $-x, 1-y,-z$ in 3$)$ distance $=3.795(4) \AA$ (in 2 ) and $3.957(8) \AA$ (in 3), a dihedral angle between the planes $=0.0(3)^{\circ}$ (in 2) and $0.0(7)^{\circ}$ (in 3) and a slippage = $1.681 \AA$ (in 2) and $1.951 \AA$ (in 3), where $C g 2$ is the centroid of the picolinic acid pyridine ring $\mathrm{N} 2 / \mathrm{C} 7-\mathrm{C} 11]$ and between picolinate pyridine rings and chelate 
rings [a $C g 3 \cdots C g 4(1-x, 1-y, 1-z$ in 2 and $1-x,-y,-z$ in 3) distance $=3.588(3) \AA$ (in 2) and $3.656(7) \AA$ (in 3), a dihedral angle between the planes $=3.7(3)^{\circ}$ (in 2) and $3.9(6)^{\circ}$ (in 3) and a slippage $=1.107 \AA$ (in 2) and $1.192 \AA$ (in 3), where $C g 3$ is the centroid of the picolinate pyridine ring $\mathrm{N} 1 / \mathrm{C} 1-\mathrm{C} 5$ and $\mathrm{Cg} 4$ is the centroid of the chelate ring $\mathrm{Hg} 1 / \mathrm{O} 1 / \mathrm{C} 6 / \mathrm{C} 1 / \mathrm{N} 1)]$ (Figure $3 b$ ).

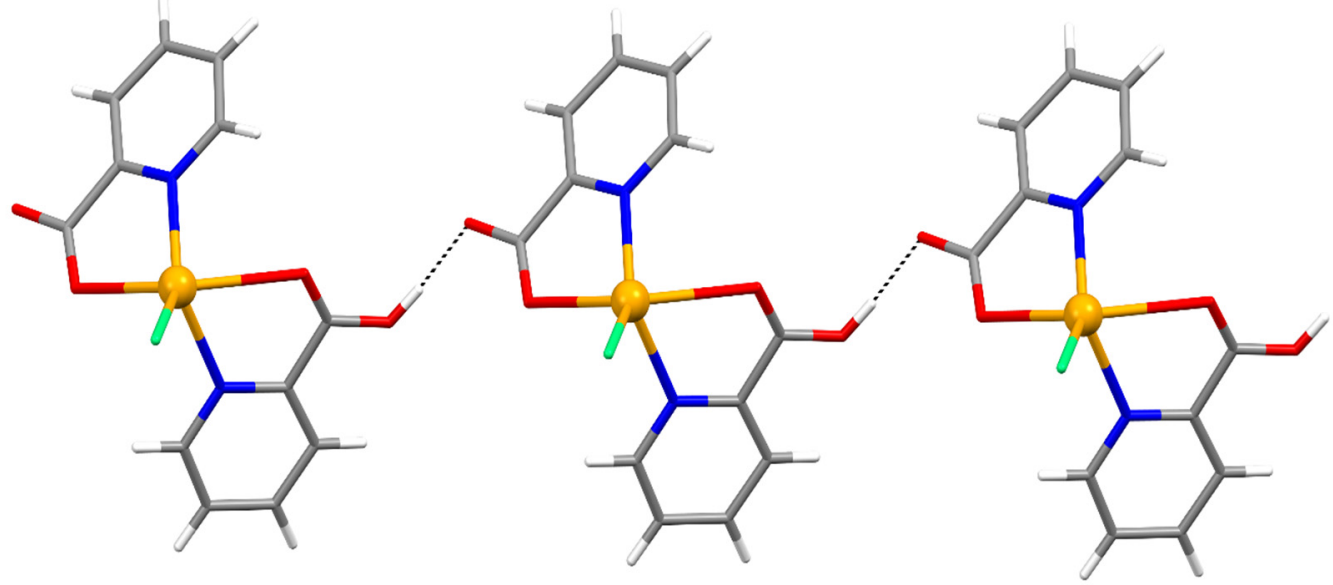

(a)

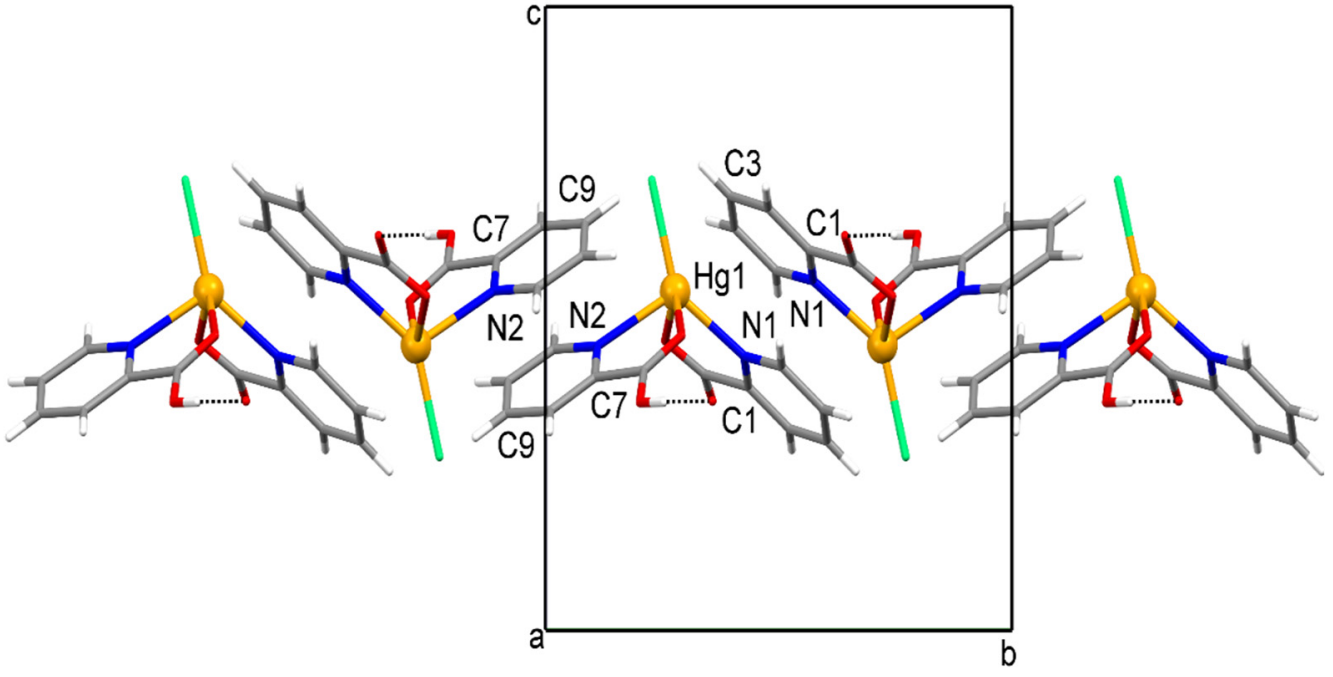

(b)

Figure 3. A hydrogen-bonded chain in the structure of $[\mathrm{HgCl}(\mathrm{pic})(\mathrm{picH})](2)$. The $[\mathrm{HgCl}(\mathrm{pic})(\mathrm{picH})]$ molecules are connected by the intermolecular $\mathrm{O}-\mathrm{H} \cdots \mathrm{O}$ hydrogen bonds (represented by the dotted lines) along the $\left[\begin{array}{lll}1 & 0 & 0\end{array}\right]$ direction, giving rise to a hydrogen-bond chain motif C11(8) (a). A fragment of the structure of $[\mathrm{HgCl}(\mathrm{pic})(\mathrm{picH})]$ (2) viewed down the $\left[\begin{array}{lll}1 & 0 & 0\end{array}\right]$ direction. The hydrogenbonded chains of $[\mathrm{HgCl}(\mathrm{pic})(\mathrm{picH})]$, represented as monomeric molecules in this projection, are connected along the $\left[\begin{array}{lll}0 & 1 & 0\end{array}\right]$ direction by $\pi-\pi$ interactions between symmetry-related picolinic acid pyridine rings (N2/C7-C11) and between picolinate pyridine rings (N1/C1-C5) and chelate rings $(\mathrm{Hg} 1 / \mathrm{O} 1 / \mathrm{C} 6 / \mathrm{C} 1 / \mathrm{N} 1)$; the selected atoms of the pyridine rings in the interactions are labeled (b).

PXRD was used to confirm the phase purity and bulk composition of compounds 1-3 (Figure 4). The powder diffraction traces (bulk sample) of all three compounds are consistent with the traces calculated from the single crystal diffraction data, indicating pure phases of compounds 1-3. The almost identical powder patterns of isostructural compounds $\mathbf{2}$ and $\mathbf{3}$ are consistent with their crystal structures. 


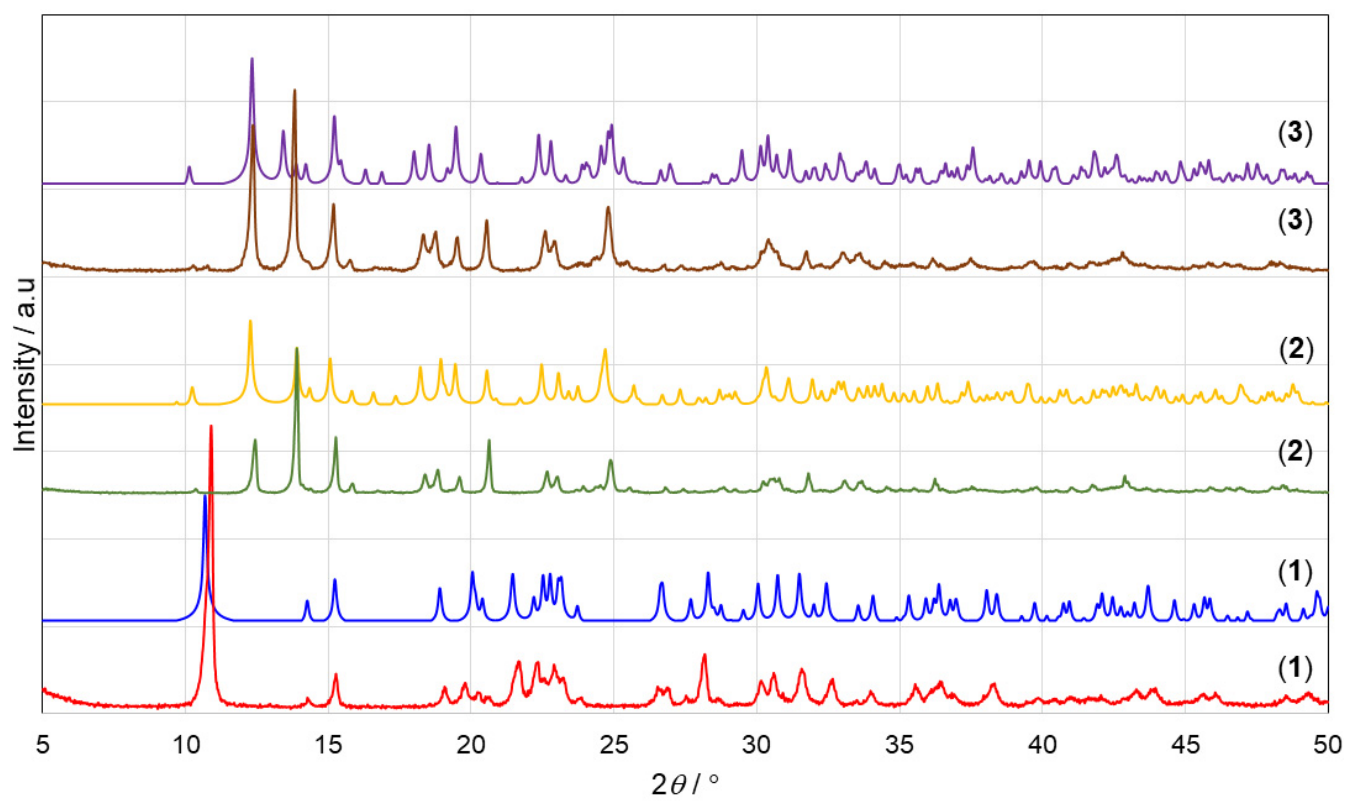

Figure 4. Overlay of experimental (red, green, brown) and calculated (blue, yellow, violet) PXRD traces for $\{[\mathrm{HgCl}(\text { pic })]\}_{n}(\mathbf{1}),[\mathrm{HgCl}($ pic $)(\mathrm{picH})](\mathbf{2})$ and $[\mathrm{HgBr}(\mathrm{pic})(\mathrm{picH})](\mathbf{3})$.

\subsection{Spectroscopic Studies (FT-IR, NMR)}

The recorded IR spectra of coordination polymer $\mathbf{1}$ and mononuclear compounds $\mathbf{2}$ and 3 (Figure S1 in the Supplementary Materials) are in a good agreement with their crystal structures. Very broad bands in the spectra of 2 and 3 centered around $3400 \mathrm{~cm}^{-1}$ can be attributed to the hydrogen-bonded $(\mathrm{O}-\mathrm{H} \cdots \mathrm{O})$ carboxylic groups $[47,48]$. The broad bands in the IR spectrum of free picH centered around 2600 and $2100 \mathrm{~cm}^{-1}$ are connected with the $\mathrm{O}-\mathrm{H} \cdots \mathrm{N}$ intermolecular hydrogen bonding. The disappearing of the above-mentioned bands from the IR spectra of the metal complexes suggests a coordination of the $\mathrm{N}$ atom to the mercury(II) ion $[48,49]$. The characteristic $v(\mathrm{C}=\mathrm{O})$ bands of the carboxylic group at $1718 \mathrm{~cm}^{-1}$ in the IR spectra of 2 and 3 are connected with the existence of neutral picolinic acid molecules $[47,48]$. On the other hand, the absence of the bands around 3400 and $1700 \mathrm{~cm}^{-1}$ in the IR spectrum of $\mathbf{1}$ indicates a complete deprotonation of the carboxylic group [41,48-51]. The IR spectra of the metal complexes show strong absorptions of the antisymmetric $v_{\text {as }}\left(\mathrm{COO}^{-}\right)$and symmetric $v_{\mathrm{s}}\left(\mathrm{COO}^{-}\right)$stretching vibrations of the carboxylate ligands in the $1650-1590 \mathrm{~cm}^{-1}$ and $1380-1350 \mathrm{~cm}^{-1}$ regions.

The ${ }^{13} \mathrm{C}$ NMR data for picH and compounds $\mathbf{1}-\mathbf{3}$ are given in Table 1 . The numeration of the atoms is consistent with the IUPAC nomenclature (Scheme 2). The complexation effects due to the mercury(II)-induced electronic redistribution throughout the coordinated ligands are well-known from the literature [18,19,41]. The NMR data of $\mathbf{1}-\mathbf{3}$ show small but significant complexation effects. The greatest changes upon complexation with mercury(II) are observed for the coordination polymer 1 . In the ${ }^{13} \mathrm{C}$ NMR spectra of all complexes, the greatest change (deshielding effect, $4.27-1.38 \mathrm{ppm}$ ) upon complexation with mercury(II) was observed for the chemical shift of the C-4 atoms. The largest shielding effects (2.89-1.66 ppm) were observed for the carboxylate carbon atoms, being only two bonds away from the coordinated mercury(II) ion. The shielding effect is consistent with a reduction of the $\pi$-electron density of the $\mathrm{C}=\mathrm{O}$ bond due to the carboxylic/carboxylate coordination to mercury. Small but significant complexation effects observed in the NMR spectra of prepared complexes are in agreement with the existence of mononuclear ( 2 and 3) and polymeric (1) species in the DMSO solutions. 
Table 1. ${ }^{13} \mathrm{C}$ NMR chemical shifts $(\delta)$ a in ppm of picH, $\{[\mathrm{HgCl}(\text { pic })]\}_{n}(\mathbf{1}),[\mathrm{HgCl}($ pic $)(\mathrm{picH})](\mathbf{2})$, and $[\mathrm{HgBr}(\mathrm{pic})(\mathrm{picH})](3)$.

\begin{tabular}{ccccccc}
\hline Compound & C-2 & C-3 & C-4 & C-5 & C-6 & COOH \\
\hline picH & 148.41 & 124.76 & 137.60 & 127.17 & 149,49 & 166.27 \\
$\mathbf{1}$ & 149.30 & 125.62 & 141.87 & 127.35 & 148.79 & 163.38 \\
$\mathbf{2}$ & 148.79 & 125.24 & 139.88 & 127.30 & 149.11 & 164.78 \\
$\mathbf{3}$ & 148.48 & 124.57 & 138.98 & 126.66 & 148.51 & 164.61 \\
\hline
\end{tabular}

${ }^{a}$ Recorded in DMSO- $d_{6}$ solutions. Referred to TMS.

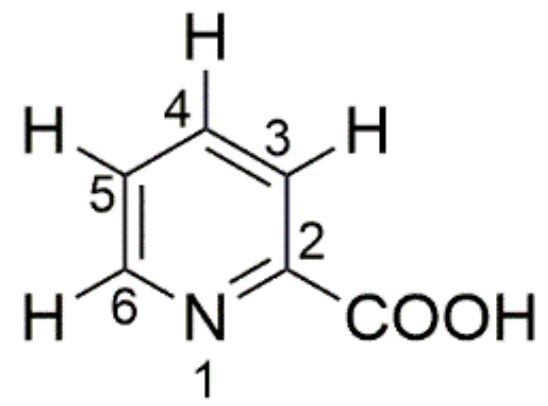

Scheme 2. Numeration of the atoms in picH.

\subsection{Thermal Analysis (TGA/DSC)}

The thermal behavior of compounds 1-3 has been investigated by simultaneous TGA/DSC analysis from room temperature up to $450{ }^{\circ} \mathrm{C}$ in flowing nitrogen (Figure S2 in the Supplementary Materials).

Continuous thermal degradation of the compounds was observed. Total weight losses of $87.28 \%$ (1), $89.42 \%$ (2), and $89.05 \%$ (3) were observed at $450{ }^{\circ} \mathrm{C}$. Thermal degradation is characterized with two (1) and one (2 and 3) signals on the DSC curves: 203 and $206{ }^{\circ} \mathrm{C}$, 206 and $204{ }^{\circ} \mathrm{C}$ respectively. According to the literature [51-53], the above-mentioned signals probably correspond to the decarboxylation of picH.

\section{Experimental Section}

\subsection{Materials and Physical Measurements}

All commercially available chemicals were of reagent grade and were used as received without further purification. CHN elemental analyses were carried out with a Perkin-Elmer 2400 Series II CHNS analyzer in Analytical Services Laboratories of the Ruđer Bošković Institute, Zagreb, Croatia. The mercury content in the complexes was determined by complexometric titration with sodium diethyldithiocarbamate of the solution obtained after decomposition of the compounds in aqua regia [54]. The $\mathrm{pH}$ values were measured by a Mettler Toledo MP220 Basic $\mathrm{pH} / \mathrm{mV} /{ }^{\circ} \mathrm{C}$ Meter.

IR spectra were obtained from KBr pellets in the range $4000-500 \mathrm{~cm}^{-1}$ on a PerkinElmer Spectrum Two FT-IR spectrometer. The one-dimensional homonuclear ${ }^{1} \mathrm{H}$ and ${ }^{13} \mathrm{C}$ NMR spectra were recorded with a Bruker AV 600 spectrometer, operating at $600.133 \mathrm{MHz}$ for the ${ }^{1} \mathrm{H}$ nucleus and $150.917 \mathrm{MHz}$ for the ${ }^{13} \mathrm{C}$ nucleus. The samples were dissolved in DMSO- $d_{6}$ in $5 \mathrm{~mm}$ NMR tubes. Chemical shifts, in ppm, are referred to TMS as internal standard.

Thermogravimetric analysis was performed using a simultaneous TGA-DSC analyzer Mettler-Toledo TGA/DSC 3+. The samples of compounds 1-3 were placed in alumina pans $(70 \mu \mathrm{L})$ and heated in flowing nitrogen $\left(50 \mathrm{~mL} \mathrm{~min}^{-1}\right)$ from room temperature up to $450{ }^{\circ} \mathrm{C}$ at a rate of $10{ }^{\circ} \mathrm{C} \mathrm{min}^{-1}$. Data collection and analysis were performed using the program package STARe Software 15.01 MettlerToledo GmbH, 2015.

Powder X-ray diffraction experiments (PXRD) were measured on a Malvern Panalytical Aeris XRD diffractometer with $\mathrm{CuK} \alpha(1.5406 \AA$ A) radiation, Ni filter, and solid-state PIXcel3D-Medipix3 detector. Samples were prepared as a thin layer on a silicon zero- 
background plate. Data were collected in the $2 \theta$ range from $5^{\circ}$ to $50^{\circ}$ with a step size of $0.02173^{\circ}$, scan rate $10 \mathrm{~s} /{ }^{\circ}, \frac{1}{4}$ inch divergence slit, and $13 \mathrm{~mm}$ beam mask.

\subsection{Syntheses of the Compounds}

3.2.1. Synthesis of $\{[\mathrm{HgCl}(\mathrm{pic})]\}_{\mathrm{n}}(\mathbf{1})$

A solution of picH $(0.23 \mathrm{~g}, 1.87 \mathrm{mmol})$ in $10 \mathrm{~mL} \mathrm{H}_{2} \mathrm{O}$ was added dropwise to a solution of $\mathrm{HgCl}_{2}(0.50 \mathrm{~g}, 1.84 \mathrm{mmol})$ in $20 \mathrm{~mL} \mathrm{H}_{2} \mathrm{O}$. An aqueous solution of $\mathrm{NaOAc}(5 \%)$ was added to the reaction mixture until precipitation of the compound was completed (increasing the $\mathrm{pH}$ from 2.38 to 2.76). The colorless product was filtered off and washed with a small amount of water and dried in air. Yield: $62 \%$ (based on $\mathrm{HgCl}_{2}$ ). Anal. Calcd for $\mathrm{HgClC}_{6} \mathrm{H}_{4} \mathrm{NO}_{5}$ : C, 20.12; H, 1.33; N, 3.91; Hg, 56.01. Found: C, 20.10; H, 1.38; N 3.91; $\mathrm{Hg}, 56.97$.

FT-IR (KBr, $\left.\mathrm{cm}^{-1}\right)$ : 1621(w), 1608(m), 1583(s), 1557(vs), 1382(m), 1367(s), 1301(w), 1260(m), 1236(w), 1169(w), 1091(w), 1055(m), 1025(m), 914(w), 834(m), 761(vs), 693(vs), 647(m), 534(w).

${ }^{1} \mathrm{H}$ NMR (DMSO- $\left.d_{6}, \mathrm{ppm}\right): 8.83\left(\mathrm{~d}, J_{\mathrm{HH}}=5.207 \mathrm{~Hz}, \mathrm{H}-6\right), 8.43\left(\mathrm{~d}, J_{\mathrm{HH}}=7782 \mathrm{~Hz}, \mathrm{H}-3\right)$, $8.27\left(\mathrm{t}, J_{\mathrm{HH}}=7599 \mathrm{~Hz}, \mathrm{H}-4\right), 7,92\left(\mathrm{t}, J_{\mathrm{HH}}=6822 \mathrm{~Hz}, \mathrm{H}-5\right)$.

Preparation of single crystals of $\{[\mathrm{HgCl}(\text { pic })]\}_{n}(\mathbf{1})$.

A solution of picH $(0.12 \mathrm{~g}, 0.97 \mathrm{mmol})$ in $10 \mathrm{~mL} \mathrm{H}_{2} \mathrm{O}$ was added dropwise to a solution of $\mathrm{HgCl}_{2}(0.30 \mathrm{~g}, 0.94 \mathrm{mmol})$ in $15 \mathrm{~mL} \mathrm{H}_{2} \mathrm{O}$. Small portions of colorless crystals of $\mathbf{1}$, suitable for single-crystal $\mathrm{X}$-ray structure determination, were formed in a few hours. The mixture of $\mathbf{1}$ and $\mathbf{2}$ was isolated by allowing the mother liquor to stand for a few days.

\subsubsection{Synthesis of $[\mathrm{HgCl}(\mathrm{pic})(\mathrm{picH})](2)$}

A solution of picH $(0.46 \mathrm{~g}, 3.74 \mathrm{mmol})$ in $20 \mathrm{~mL} \mathrm{MeOH}$ was added dropwise to a solution of $\mathrm{HgCl}_{2}(0.50 \mathrm{~g}, 1.84 \mathrm{mmol})$ in $10 \mathrm{~mL} \mathrm{MeOH}$. Colorless crystals suitable for single-crystal X-ray structure determination were formed in a few days. The colorless crystals were filtered off, washed with $\mathrm{MeOH}$, and dried in air. Yield: $48 \%$ (based on $\mathrm{HgCl}_{2}$ ). Anal. Calc. for $\mathrm{HgClC}_{12} \mathrm{H}_{9} \mathrm{~N}_{2} \mathrm{O}_{4}: \mathrm{C} 29.95, \mathrm{H} 1.89, \mathrm{~N} 5.82, \mathrm{Hg} 41.68$. Found: C 29.80, $\mathrm{H} 2.07$, N 5.79, Hg 41.54\%.

FT-IR (KBr, cm $\left.{ }^{-1}\right)$ : 3473(m), 1718(m), 1656(s), 1642(s), 1625(s), 1592(vs), 1569(s), 1440(m), 1383(vs), 1295(s), 1259(m), 1238(m), 1156(m), 1050(m), 1018(m), 998(m), 838(m), 752(s), 698(s), 688(s), 641(w), 624(w), 507(w).

${ }^{1} \mathrm{H}$ NMR (DMSO- $\left.d_{6}, \mathrm{ppm}\right): 8.77\left(\mathrm{~d}, J_{\mathrm{HH}}=5.008 \mathrm{~Hz}, \mathrm{H}-6\right), 8.26\left(\mathrm{~d}, J_{\mathrm{HH}}=7.722 \mathrm{~Hz}, \mathrm{H}-3\right)$, $8.14\left(\mathrm{t}, J_{\mathrm{HH}}=7.593 \mathrm{~Hz}, \mathrm{H}-4\right), 7,78\left(\mathrm{t}, J_{\mathrm{HH}}=6.379 \mathrm{~Hz}, \mathrm{H}-5\right)$.

\subsubsection{Synthesis of $[\mathrm{HgBr}(\mathrm{pic})(\mathrm{picH})](3)$}

A solution of picH $(0.35 \mathrm{~g}, 2.84 \mathrm{mmol})$ in $15 \mathrm{~mL} \mathrm{MeOH}$ was added dropwise to a solution of $\mathrm{HgBr}_{2}(0.50 \mathrm{~g}, 1.39 \mathrm{mmol})$ in $15 \mathrm{~mL} \mathrm{MeOH}$. Colorless crystals suitable for single-crystal X-ray structure determination were formed in a few days. The colorless crystals were filtered off, washed with $\mathrm{MeOH}$, and dried in air. Yield: $49 \%$ (based on $\mathrm{HgBr}_{2}$ ). Anal. Calc. for $\mathrm{HgBrC}_{12} \mathrm{H}_{9} \mathrm{~N}_{2} \mathrm{O}_{4}$ : C 27.39, H 1.73, N 5.33, $\mathrm{Hg}$ 38.16. Found: C 27.29, $\mathrm{H} 1.71, \mathrm{~N} 5.47, \mathrm{Hg} 37.98 \%$.

FT-IR (KBr, cm $\left.{ }^{-1}\right)$ : 3472(m), 3075(m), 1718(m), 1656(s), 1634(vs), 1618(s), 1593(vs), 1569(s), 1520(w), 1446(w), 1383(vs), 1295(s), 1258(m), 1242(m), 1157(w), $1090(\mathrm{~m}), 1051(\mathrm{w})$, 1018(w), 998(m), 837(m), 753(s), 699(s), 688(s), 641(w), 624(w), 514(w).

${ }^{1} \mathrm{H}$ NMR (DMSO- $\left.d_{6}, \mathrm{ppm}\right): 8.73\left(\mathrm{~d}, J_{\mathrm{HH}}=4279 \mathrm{~Hz}, \mathrm{H}-6\right), 8.23\left(\mathrm{~d}, J_{\mathrm{HH}}=7.756 \mathrm{~Hz}, \mathrm{H}-3\right)$, $8.10\left(\mathrm{t}, J_{\mathrm{HH}}=7.633 \mathrm{~Hz}, \mathrm{H}-4\right), 7,74\left(\mathrm{t}, J_{\mathrm{HH}}=8.266 \mathrm{~Hz}, \mathrm{H}-5\right)$.

\subsection{X-ray Crystallographic Analysis}

Suitable single crystals of 1-3 were selected and mounted in Paratone-N oil onto cryoloops. Data collection was carried out on an XtaLAB Synergy-S Dualflex diffractometer with PhotonJet (Mo) microfocus X-ray source and HyPix-6000HE hybrid photon counting (HPC) X-ray area detector, using graphite monochromated $\operatorname{MoK} \alpha(\lambda=0.71073 \AA)$ radiation 
at low temperature (170(2) K) and by applying the CrysAlisPro Software system [55]. Data reduction and cell refinement were performed by the CrysAlisPro Software system [55]. The structures were solved by SHELXT [56] and refined by SHELXL-2018/3 [57]. The refinement procedure was done by the full-matrix least-squares methods based on $F^{2}$ values against all reflections. The figures were made with MERCURY (Version 2020.2.0) [58]. The crystallographic data for $\mathbf{1 - 3}$ are summarized in Table 2.

Table 2. Crystallographic data for $\{[\mathrm{HgCl}(\text { pic) })]\}_{n}$ (1), $[\mathrm{HgCl}($ pic) $($ picH) $)]$ (2) and $[\mathrm{HgBr}(\mathrm{pic})(\mathrm{picH})]$ (3).

\begin{tabular}{cccc}
\hline Compound & $\mathbf{1}$ & $\mathbf{2}$ & $\mathbf{3}$ \\
\hline Formula & $\mathrm{C}_{6} \mathrm{H}_{4} \mathrm{HgClNO}_{2}$ & $\mathrm{C}_{12} \mathrm{H}_{9} \mathrm{HgClN}_{2} \mathrm{O}_{4}$ & $\mathrm{C}_{12} \mathrm{H}_{9} \mathrm{HgBrN}_{2} \mathrm{O}_{4}$ \\
$M_{\mathrm{r}}$ & 358.14 & 481.25 & 525.71 \\
Crystal system, space & monoclinic, $P 2_{1} / c$ & monoclinic, $P 2_{1} / c$ & monoclinic, $P 2_{1} / c$ \\
group & $(\mathrm{No} .14)$ & $($ No. 14$)$ & $(\mathrm{No})$. 14$)$ \\
$a(\AA)$ & $9.0131(6)$ & $9.1384(5)$ & $9.1223(4)$ \\
$b(\AA)$ & $8.8569(4)$ & $11.7625(8)$ & $11.6466(6)$ \\
$c(\AA)$ & $9.4804(6)$ & $12.7526(7)$ & $13.1976(6)$ \\
$\beta\left({ }^{\circ}\right)$ & $113.292(7)$ & $92.798(5)$ & $92.073(4)$ \\
$V\left(\AA^{3}\right)$ & $695.12(8)$ & $1369.15(14)$ & $1401.25(11)$ \\
$Z$ & 4 & 4 & 4 \\
$D_{\text {calc }}\left(\mathrm{g} \mathrm{cm}^{-3}\right)$ & 3.422 & 2.335 & 2.492 \\
$\mu\left(\mathrm{mm}^{-1}\right)$ & 22.462 & 11.450 & 13.848 \\
$R[I \geq 2 \sigma(I)]$ & 0.0265 & 0.0325 & 0.0575 \\
wR $[$ all data $]$ & 0.0652 & 0.0804 & 0.1896 \\
\hline
\end{tabular}

\section{Conclusions}

The neighboring mercury(II) ions are bridged by an $\mathrm{N}, \mathrm{O}, \mathrm{O}^{\prime}$-picolinate ion into a polymeric chain of $\mathbf{1}$, while both complexes $\mathbf{2}$ and $\mathbf{3}$ are mononuclear, containing the respective halide ion and $\mathrm{N}, \mathrm{O}$-bidentate picolinate ion and picolinic acid molecule. It is possible to control both the composition and dimensionality of the mercury(II) complexes formed in the system containing mercury(II), picolinic acid, halide ions, and a solvent. This control was achieved by varying the solvent type and metal-to-ligand ratio in this system. The IR, ${ }^{1} \mathrm{H}$, and ${ }^{13} \mathrm{C}$ NMR data correlate well with the solid-state structures of $\mathbf{1}, \mathbf{2}$, and $\mathbf{3}$. According to the NMR data, there is no decomposition of $\mathbf{1}, \mathbf{2}$, and $\mathbf{3}$ in the respective DMSO solutions and $\mathbf{1}$ remains polymeric, while $\mathbf{2}$ and $\mathbf{3}$ remain mononuclear in the solutions. The observed differences in the chemical shifts were ascribed to complexation effects and were reliable enough to distinguish between polymeric (1) and monomeric (2 and 3) compounds.

Supplementary Materials: Table S1: Selected bond lengths $(\AA)$ and angles $\left({ }^{\circ}\right)$ for $\{[\mathrm{HgCl}(\text { pic })]\}_{n}$ (1), $[\mathrm{HgCl}(\mathrm{pic})(\mathrm{picH})](2)$ and $[\mathrm{HgBr}(\mathrm{pic})(\mathrm{picH})](3)$, Table S2: The hydrogen bond geometry for $\{[\mathrm{HgCl}(\mathrm{pic})]\}_{n}(\mathbf{1}),[\mathrm{HgCl}(\mathrm{pic})(\mathrm{picH})](\mathbf{2})$ and $[\mathrm{HgBr}(\mathrm{pic})(\mathrm{picH})](\mathbf{3})$, Figure S1: IR spectra of $\{[\mathrm{HgCl}(\mathrm{pic})]\}_{n}$ (1), $[\mathrm{HgCl}(\mathrm{pic})(\mathrm{picH})]\left(\right.$ (2) and $[\mathrm{HgBr}(\mathrm{pic})(\mathrm{picH})]$ (3), Figure S2: TGA/DSC curves of $\{[\mathrm{HgCl}(\mathrm{pic})]\}_{n}$ (1), [ $\mathrm{HgCl}(\mathrm{pic})(\mathrm{picH})]$ (2) and [HgBr(pic)(picH)] (3). Deposition numbers 2092545 (for 1), 2092546 (for 2) and 2092547 (for 3) contain the supplementary crystallographic data for this paper. These data are provided free of charge by the joint Cambridge Crystallographic Data Centre and Fachinformationszentrum Karlsruhe Access Structures service www.ccdc.cam.ac.uk/structures.

Author Contributions: Conceptualization, B.-M.K. and Ž.S.; methodology, B.-M.K., Ž.S. and D.M.-Č.; validation, B.-M.K. and Ž.S.; formal analysis, B.-M.K. and Ž.S.; investigation, B.-M.K., Ž.S., D.M.-Č. and Z.P.; resources, Z.P.; data curation, Ž.S. and Z.P.; writing—original draft preparation, B.-M.K. and Ž.S.; writing—review and editing, B.-M.K., Ž.S., D.M.-Č. and Z.P.; visualization, B.-M.K.; supervision, Z.P.; project administration, Z.P.; funding acquisition, Z.P. All authors have read and agreed to the published version of the manuscript.

Funding: This research was funded by University of Zagreb, Zagreb, Croatia (Grant No. 118120281106) and by the Ministry of Science, Education and Sports of the Republic of Croatia (Grant No. 1191193079-1332). The APC were waived in full by the Publisher. 
Institutional Review Board Statement: Not applicable.

Informed Consent Statement: Not applicable.

Conflicts of Interest: The authors declare no conflict of interest. The funders had no role in the design of the study; in the collection, analyses, or interpretation of data; in the writing of the manuscript, or in the decision to publish the results.

Sample Availability: Samples of the compounds 1-3 are available from the authors.

\section{References}

1. Sunday, N.F. Emerging Trends in Coordination Polymers and Metal-Organic Frameworks: Perspectives, Synthesis, Properties and Applications. Arch. Org. Inorg. Chem. Sci. 2018, 1, 001-012. [CrossRef]

2. Morsali, A.; Masoomi, M.Y. Structures and properties of mercury(II) coordination polymers. Coord. Chem. Rev. 2009, 253, 1882-1905. [CrossRef]

3. Mahata, P.; Natarajan, S. Pyridine- and Imidazoledicarboxylates of Zinc: Hydrothermal Synthesis, Structure, and Properties. Eur. J. Inorg. Chem. 2005, 2005, 2156-2163. [CrossRef]

4. Dos Santos Chagas, C.; Fonseca, F.L.A.; Bagatin, I.A. Quinoline-derivative coordination compounds as potential applications to antibacterial and antineoplasic drugs. Mater. Sci. Eng. C 2019, 98, 1043-1052. [CrossRef]

5. Sudik, A.C.; Millward, A.R.; Ockwig, N.W.; Côté, A.P.; Kim, J.; Yaghi, O.M. Design, synthesis, structure, and gas ( $\mathrm{N}_{2}$, Ar, $\mathrm{CO}_{2}$, $\mathrm{CH}_{4}$, and $\mathrm{H}_{2}$ ) sorption properties of porous metal-organic tetrahedral and heterocuboidal polyhedra. J. Am. Chem. Soc. 2005, 127, 7110-7118. [CrossRef]

6. $\quad$ Fang, Q.-R.; Zhu, G.-S.; Xue, M.; Sun, J.-Y.; Qiu, S.-L. Porous coordination polymers with zeolite topologies constructed from 4-connected building units. Dalton Trans. 2006, 2399-2402. [CrossRef]

7. Han, H.; Zhang, S.; Hou, H.; Fan, Y.; Zhu, Y. Fe(Cu)-Containing Coordination Polymers: Syntheses, Crystal Structures, and Applications as Benzyl Alcohol Oxidation Catalysts. Eur. J. Inorg. Chem. 2006, 2006, 1594-1600. [CrossRef]

8. Liu, Q.-X.; Yin, L.-N.; Wu, X.-M.; Feng, J.-C.; Guo, J.-H.; Song, H.-B. New N-heterocyclic carbene mercury(II) and silver(I) complexes. Polyhedron 2008, 27, 87-94. [CrossRef]

9. Liu, B.; Guo, G.-C.; Huang, J.-S. Four triazole-bridging coordination polymers containing (m-phenol)-1,2,4-triazole: Syntheses, structures and properties of fluorescence and magnetism. J. Solid State Chem. 2006, 179, 3136-3144. [CrossRef]

10. Wang, J.W.; Zhang, M.C. Fluorescence and crystal structures of new mercury(II) macrocyclic N-heterocyclic carbene complexes with ether chains. J. Struct. Chem. 2014, 55, 703-708. [CrossRef]

11. Chen, Z.; Wu, X.; Qin, S.; Lei, C.; Liang, F. Structure and fluorescent properties of mercury(II) pyridine-2,3-dicarboxylate coordination polymers tuned by ancillary ligands and alkaline-earth metal ions. CrystEngComm 2011, 13, 2029-2038. [CrossRef]

12. Mahmoudi, G.; Morsali, A. Counter-ion influence on the coordination mode of the 2,5-bis(4-pyridyl)-1,3,4-oxadiazole (bpo) ligand in mercury(II) coordination polymers, $\left[\mathrm{Hg}(\mathrm{bpo})_{n} \mathrm{X}_{2}\right]$ : $\mathrm{X}=\mathrm{I}^{-}, \mathrm{Br}^{-}, \mathrm{SCN}^{-}, \mathrm{N}_{3}{ }^{-}$and $\mathrm{NO}_{2}{ }^{-}$; spectroscopic, thermal, fluorescence and structural studies. CrystEngComm 2007, 9, 1062-1072. [CrossRef]

13. Ciurtin, D.M.; Pschirer, N.G.; Smith, M.D.; Bunz, U.H.F.; zur Loye, H.-C. Two luminescent coordination polymers with a triple-helix structure: $\mathrm{HgX}_{2}\left(\mathrm{C}_{31} \mathrm{H}_{24} \mathrm{~N}_{2}\right) \cdot \mathrm{CH}_{2} \mathrm{Cl}_{2}(\mathrm{X}=\mathrm{Cl}$ and $\mathrm{Br})$. Chem. Mater. 2001, 13, 2743-2745. [CrossRef]

14. Soldin, Z.; Matković-Čalogović, D.; Pavlović, G.; Popovic, J.; Vinković, M.; Vikić-Topić, D.; Popović, Z. Various coordination modes in mercury(II) complexes with quinoline-2-carboxylic acid: Preparation and structural characterization. Polyhedron 2009, 28, 2735-2743. [CrossRef]

15. Morsali, A.; Zhu, L.-G. A novel one-dimensional helical chain polymer involving both tetra- and hexacoordinate mercury(II) ions. Inorg. Chem. Commun. 2004, 7, 1184-1187. [CrossRef]

16. Popović, Z.; Pavlović, G.; Matković-Čalogović, D.; Soldin, Ž. Polymeric $\mu$-bromo- $\mu$-pyridine-3-carboxylato- $\kappa^{3} \mathrm{O}, \mathrm{O}^{\prime}: \mathrm{N}-\mathrm{mercury}(\mathrm{II})$. Acta Crystallogr. 2003, C59, m165-m167. [CrossRef]

17. Popović, Z.; Pavlović, G.; Soldin, Ž. Iodo(picolinato- $\left.\kappa^{2} N, O\right)\left(\right.$ picolinic acid- $\left.\kappa^{2} N, O\right)$ mercury(II). Acta Crystallogr. 2006, C62, $\mathrm{m} 272-\mathrm{m} 274$. [CrossRef]

18. Soldin, Ž.; Kukovec, B.-M.; Matković-Čalogović, D.; Popović, Z. A design of mercury(II) coordination polymers with pyridinedicarboxylic acids: Structural, spectroscopic and thermal studies. J. Inorg. Organomet. Polym. 2018, 28, 2080-2089. [CrossRef]

19. Soldin, Ž.; Kukovec, B.-M.; Matković-Čalogović, D.; Popović, Z. Hydrogen-bonded frameworks of mercury(II) complexes with pyridinedicarboxylic acids. Aust. J. Chem. 2018, 71, 455-462. [CrossRef]

20. Seetharaj, R.; Vandana, P.V.; Arya, P.; Mathew, S. Dependence of solvents, $\mathrm{pH}$, molar ratio and temperature in tuning metal organic framework architecture. Arab. J. Chem. 2019, 12, 295-315. [CrossRef]

21. Slenters, T.V.; Sagué, J.L.; Brunetto, P.S.; Zuber, S.; Fleury, A.; Mirolo, L.; Robin, A.Y.; Meuwly, M.; Gordon, O.; Landmann, R.; et al. Of Chains and Rings: Synthetic Strategies and Theoretical Investigations for Tuning the Structure of Silver Coordination Compounds and Their Applications. Materials 2010, 3, 3407-3429. [CrossRef]

22. Sanii, R.; Hua, C.; Patyk-Kaźmierczak, E.; Zaworotko, M.J. Solvent-directed control over the topology of entanglement in square lattice (sql) coordination networks. Chem. Commun. 2019, 55, 1454-1457. [CrossRef] 
23. Notash, B.; Rezaei Kheirkhah, B. The effect of solvent on one-dimensional cadmium coordination polymers. New J. Chem. 2018, 42, 15014-15021. [CrossRef]

24. Pan, L.; Frydel, T.; Sander, M.B.; Huang, X.; Li, J. The effect of $\mathrm{pH}$ on the dimensionality of coordination polymers. Inorg. Chem. 2001, 40, 1271-1283. [CrossRef] [PubMed]

25. Braga, D.; Brammer, L.; Champness, N.R. New trends in crystal engineering. CrystEngComm 2005, 7, 1-19. [CrossRef]

26. Brammer, L. Developments in inorganic crystal engineering. Chem. Soc. Rev. 2004, 33, 476-489. [CrossRef]

27. Desiraju, G.R. Crystal engineering: A holistic view. Angew. Chem. Int. Ed. 2007, 46, 8342-8356. [CrossRef] [PubMed]

28. Hollingsworth, M.D. Crystal engineering: From structure to function. Science 2002, 295, 2410-2413.

29. Braga, D. Crystal engineering, Where from? Where to? Chem. Commun. 2003, 2751-2754. [CrossRef]

30. Tessarolo, J.; Venzo, A.; Bottaro, G.; Armelao, L.; Rancan, M. Hampered Subcomponent Self-Assembly Leads to an Aminal Ligand: Reactivity with Silver(I) and Copper(II). Eur. J. Inorg. Chem. 2016, 2017, 30-34. [CrossRef]

31. Cevik, S.; Telli, B.; Dal, H.; Sari, M. A Tridentate In Situ Generated Ligand Leading the Self-Assembly of a Transition Metal Coordination Polymer: Solvothermal Synthesis and Structural Characterization of 1D Cadmium Pyridine-2-Carboxylate. Synth. React. Inorg. Met. Chem. 2014, 45, 139-144. [CrossRef]

32. Wu, A.-Q.; Guo, G.-H.; Yang, C.; Zheng, F.-K.; Liu, X.; Guo, G.-C.; Huang, J.-S.; Dong, Z.-C.; Takano, Y. Extended Structures and Magnetic Properties of Lanthanide-Copper Complexes with Picolinic Acids as Bridging Ligands. Eur. J. Inorg. Chem. 2005, 2005, 1947-1954. [CrossRef]

33. Deloume, J.P.; Loiseleur, H. Structure cristalline du pyridine-2 carboxylate de cadmium. Acta Crystallogr. Sect. B Struct. Crystallogr. Cryst. Chem. 1974, 30, 607-609. [CrossRef]

34. Ay, B.; Şahin, O.; Yildiz, E. One-Pot hydrothermal synthesis of 1D copper (II) coordination polymers involving in-situ decarboxylation. Solid State Sci. 2019, 96, 105958. [CrossRef]

35. Wang, Y.-T.; Fan, H.-H.; Wang, H.-Z.; Chen, X.-M. A Solvothermally in Situ Generated Mixed-ligand Approach for NLO-Active Metal-Organic Framework Materials. Inorg. Chem. 2005, 44, 4148-4150. [CrossRef]

36. Payehghadr, M.; Safarifard, V.; Ramazani, M.; Morsali, A. Preparation of Cadmium(II) Oxide Nanoparticles from a New OneDimensional Cadmium(II) Coordination Polymer Precursor; Spectroscopic and Thermal Analysis Studies. J. Inorg. Organomet. Polym. Mater. 2012, 22, 543-548. [CrossRef]

37. Enthaler, S.; Wu, X.-F.; Weidauer, M.; Irran, E.; Döhlert, P. Exploring the coordination chemistry of 2-picolinic acid to zinc and application of the complexes in catalytic oxidation chemistry. Inorg. Chem. Commun. 2014, 46, 320-323. [CrossRef]

38. Żurowska, B.; Slepokura, K. Structure and magnetic properties of polynuclear copper(II) compounds with syn-anti carboxylatoand bromo-bridges. Inorganica Chim. Acta 2008, 361, 1213-1221. [CrossRef]

39. Groom, C.R.; Bruno, I.J.; Lightfoot, M.P.; Ward, S.C. The Cambridge Structural Database. Acta Crystallogr. 2016, B72, 171-179. [CrossRef]

40. Álvarez-Larena, A.; Piniella, J.F.; Pons, J.; March, R.; Casabó, J. Crystal structure of catena\{bis[ $\mu$-(2-pyridinecarboxilato- $\mu$ $\mathrm{O} 2, \mathrm{O} 1, \mathrm{~N})]$ mercury(II), $\mathrm{Hg}\left(\left(\mathrm{C}_{5} \mathrm{H}_{4} \mathrm{~N}\right)\left(\mathrm{CO}_{2}\right)\right)_{2}$. Z. Kristallogr. 1994, 209, 695. [CrossRef]

41. Gonzàlez-Duarte, P.; Leiva, A.; March, R.; Pons, J.; Clegg, W.; Solans, X.; Álvarez-Larena, A.; Piniella, J.F. Reactions of mercury(II) with 2-pyridinecarboxylic and 6-methyl-2-pyridinecarboxylic acids and corresponding esters. Crystal structures of [Hg(C5H4NCOO)2], [HgX2(C5H4NCOOPri)], X = Br or I and [HgCl2(MeC5H3NCOOEt)]. Polyhedron 1998, 17, 1591-1600. [CrossRef]

42. Hayati, P.; Gutiérrez, A. The role of non-covalent interactions on supramolecular assembly of coordination compounds of mercury(II) based on substituted pyridine mixed ligands. A survey of different conditions on morphology of new flower and ribbon like submicro structures. Inorg. Chim. Acta 2018, 479, 83-96. [CrossRef]

43. Álvarez-Larena, A.; Clegg, W.; Cucurull-Sánchez, L.; González-Duarte, P.; March, R.; Piniella, J.F.; Pons, J.; Solans, X. Mercury(II) halide adducts of esters of 2-pyridinecarboxylic acid. Crystal structures and structural variations within the series $\left[\mathrm{HgCl}_{2}\left(\mathrm{C}_{5} \mathrm{H}_{4} \mathrm{NCOOR}\right)\right], \mathrm{R} .=\mathrm{Me}, \mathrm{Et}, \mathrm{Pr}^{\mathrm{n}}$, Pri . Inorg. Chim. Acta 1997, 266, 81-90. [CrossRef]

44. Yang, L.; Powell, D.R.; Houser, R.P. Structural variation in copper(I) complexes with pyridylmethylamide ligands: Structural analysis with a new four-coordinate geometry index, $\tau_{4}$. Dalton Trans. 2007, 955-964. [CrossRef] [PubMed]

45. Addison, A.W.; Nageswara Rao, T.; Reedijk, J.; van Rijn, J.; Verschoor, G.C. Synthesis, structure, and spectroscopic properties of copper(II) compounds containing nitrogen-sulphur donor ligands; the crystal and molecular structure of aqua [1,7-bis( $N$ methylbenzimidazol-2'-yl)-2,6-dithiaheptane]copper(II) perchlorate. J. Chem. Soc. Dalton Trans. 1984, 1349-1356. [CrossRef]

46. Janiak, C. A critical account on $\pi-\pi$ stacking in metal complexes with aromatic nitrogen-containing ligands. J. Chem. Soc. Dalton Trans. 2000, 3885-3896. [CrossRef]

47. Koczoń, P.; Dobrowolski, J.C.; Lewandowski, W.; Mazurek, A.P. Experimental and theoretical IR and Raman spectra of picolinic, nicotinic and isonicotinic acids. J. Mol. Struct. 2003, 655, 89-95. [CrossRef]

48. Goher, M.A.S.; Abu-Youssef, M.A.M.; Mautner, F. Synthesis, spectral and structural characterization of a monomeric chloro complex of Zinc(II) with picolinic acid, $\left[\mathrm{Zn}\left(\mathrm{C}_{5} \mathrm{H}_{4} \mathrm{NCO}_{2} \mathrm{H}\right)\left(\mathrm{C}_{5} \mathrm{H}_{4} \mathrm{NCO}_{2}\right) \mathrm{Cl}\right.$. Polyhedron 1996, 15, 453-457. [CrossRef]

49. Mautner, F.; Abu-Youssef, M.A.M.; Goher, M.A.S. Polymeric complexes of cadmium(II) bridged simultaneously by tetradentate picolinato and $\mu(1,1)$-azido or $\mu(\mathrm{N}, \mathrm{S})$-thiocyanato anions. Synthesis and structural characterization of $\left[\mathrm{Cd}(\mathrm{p} \text { icolinato })\left(\mathrm{N}_{3}\right)\right]_{n}$ and [Cd(picolinato)(NCS) $]_{n}$. Polyhedron 1997, 16, 235-242. [CrossRef] 
50. Goher, M.A.S.; Abu-Youssef, M.A.M.; Mautner, F.; Popitsch, A. Preparation and structural characterization of catena- $\mu(1,3)-a z i d o-$ $\mu\left(\mathrm{O}, \mathrm{N}\right.$-picolinato)-aquamanganese(II), $\mathrm{Mn}\left(\mathrm{NC}_{5} \mathrm{H}_{4} \mathrm{CO}_{2}\right)\left(\mathrm{N}_{3}\right)\left(\mathrm{H}_{2} \mathrm{O}\right)$. Polyhedron 1992, 11, 2137-2141. [CrossRef]

51. Vargová, Z.; Zeleňák, V.; Císaøová, I.; Györyová, K. Correlation of thermal and spectral properties of zinc(II) complexes of pyridinecarboxylic acids with their crystal structures. Thermochim. Acta 2004, 423, 149-157. [CrossRef]

52. Ghosh, S.; Sur, B.; Ray, S.K.; Ray, P.K. A study of solid-state thermal decomposition characteristics of some metallo-organic compounds. J. Therm. Anal. Calorim. 1985, 30, 353-363. [CrossRef]

53. D'ascenzo, G.; Wendlandt, W.W. The thermal properties of some metal pyridinecarboxylates. Anal. Chim. Acta 1970, 50, 79-91. [CrossRef]

54. Gouverneur, P.; Hoedeman, W. The determination of mercury in organic compounds. Anal. Chim. Acta 1964, 30, 519-523. [CrossRef]

55. Rikagu Oxford Diffraction. CrysAlisPro; Agilent Technologies Inc.: Yarnton, UK, 2020.

56. Sheldrick, G.M. SHELXT- Integrated space-group and crystal-structure determination. Acta Crystallogr. Sect. A Found. Adv. 2015, 71, 3-8. [CrossRef]

57. Sheldrick, G.M. Crystal structure refinement withSHELXL. Acta Crystallogr. Sect. C Struct. Chem. 2015, 71, 3-8. [CrossRef] [PubMed]

58. Macrae, C.F.; Sovago, I.; Cottrell, S.J.; Galek, P.T.A.; McCabe, P.; Pidcock, E.; Platings, M.; Shields, G.P.; Stevens, J.S.; Towler, M.; et al. Mercury 4.0: From visualization to analysis, design and prediction. J. Appl. Crystallogr. 2020, 53, $226-235$. [CrossRef] 